\title{
Herbage accumulation, nutritive value and persistence of Mulato II in Florida
}

\author{
JOAO M.B. VENDRAMINI ${ }^{1}$, LYNN E. SOLLENBERGER ${ }^{2}$, GRAHAM C. LAMB ${ }^{3}$ AND \\ MARIA L. SILVEIRA ${ }^{1}$ \\ ${ }^{1}$ University of Florida, IFAS Range Cattle Research and Education Center, Ona, FL, USA. www.rcrec-ona.ifas.ufl.edu \\ ${ }^{2}$ University of Florida, IFAS Agronomy Department, Gainesville, FL, USA. www.agronomy.ifas.ufl.edu \\ ${ }^{3}$ University of Florida, IFAS North Florida Research and Education Center, Marianna, FL, USA. www.nfrec.ifas.ufl.edu
}

Keywords: Warm-season grass, Brachiaria, grazing management, stubble height, animal performance, beef cattle.

\section{Introduction}

Grasses in the Brachiaria genus are the most widely grown forages in tropical America, occupying over 80 Mha (Boddey et al. 2004). Mulato II is apomictic and a vigorous, semi-erect cultivar resulting from 3 generations of crosses including original crosses between ruzigrass (B. ruziziensis) and signalgrass $(B$. decumbens cv. Basilisk, apomictic tetraploid). According to Peters et al. (2003), Mulato produced 25\% more herbage mass than palisadegrass (Brachiaria brizantha) and koroniviagrass (B. humidicola) under similar management practices. Although Mulato II shows promise as forage in tropical regions, herbage accumulation and persistence in subtropical areas is unknown. This publication summarizes results of the research with Mulato II conducted in Florida in the last 5 years.

\section{Methods}

\section{South Florida}

This experiment was conducted on Mulato II in Ona, FL $\left(27^{\circ} 26^{\prime} \mathrm{N}, 82^{\circ} 55^{\prime} \mathrm{W}\right)$ between August and November in 2007 and 2008. Treatments were the factorial combinations of 3 stubble heights $(2.5,7.5$ and $12.5 \mathrm{~cm})$ and 2 harvest frequencies ( 2 and 4 weeks) in a randomized complete block design with 4 replicates. Plot size was $3 \times 2 \mathrm{~m}$ with $1-\mathrm{m}$ alley between plots. Samples were analyzed for in vitro digestible organic matter (IVDOM) and crude protein $(\mathrm{CP})$ concentrations. Mulato II ground cover was determined as a measurement of persistence at the end of the experimental period using a $1-\mathrm{m}^{2}$ quadrat

Correspondence: Joao M.B. Vendramini, University of Florida, IFAS Range Cattle Research and Education Center, 3401 Experiment Station, Ona, FL 33865, USA.

Email: jv@ufl.edu divided into 100 squares. The proportion of squares with Mulato II plants was reported.

\section{Central Florida}

The study was conducted in Gainesville, FL $\left(29^{\circ} 44^{\prime} \mathrm{N}\right.$, $82^{\circ} 16^{\prime}$ W) from June 2008 to June 2010. Treatments were Mulato II treated as an annual (planted in 2008 and 2009), Mulato II treated as a perennial (planted in 2008 only), Tifton 85 (Cynodon hybrid) (planted in 2008), and Tifleaf 3 pearl millet (Pennisetum glaucum) and Hayday sorghum-sudangrass (Sorghum bicolor) (both planted in 2008 and 2009), arranged in a randomized complete block design with 4 replicates. The annual treatment for Mulato II was included to compare the use of this grass with the annual species pearl millet and sorghumsudangrass, while the perennial Mulato II treatment was included to compare persistence and productivity over time with Tifton 85 bermudagrass. Plots were $5 \times 5 \mathrm{~m}$ with a $1-\mathrm{m}$ alley between plots. Seeded grass was planted on June 2008 and 2009. Tifton 85 was planted vegetatively using 100 plugs per plot. In general, perennials were harvested every 5-6 weeks throughout the summer, with slightly longer intervals during cool autumn weather. An area of $2.88 \mathrm{~m}^{2}$ was harvested with a sickle-bar mower from the center of the plot to a $10-\mathrm{cm}$ stubble height. Herbage accumulation, IVDOM and CP were determined. A $2 \mathrm{~m} \times 0.5 \mathrm{~m}$-frame, divided into 100 squares, was placed at 3 locations in each plot to determine the persistence of the plants at the end of the experimental period in 2009 and 2010. At each location where the frame was placed, cover was estimated visually in 25 of these squares. Cover was the average of the 75 estimates per plot.

\section{North Florida}

The study was conducted in Marianna, FL $\left(30^{\circ} 52^{\prime} \mathrm{N}\right.$, $\left.85^{\circ} 11^{\prime} \mathrm{W}\right)$. Treatments were 3 forage species, Tifleaf 3 
pearl millet, Hayday sorghum-sudangrass and Mulato II arranged in a completely randomized design with 3 replicates. Pastures (0.6-ha experimental units) were established in June 2008 and June 2009 in a prepared seedbed. Pastures were stocked continuously using a variable stocking rate. Two heifers (Angus crossbred) were assigned as testers to each experimental unit. Additional heifers of comparable age and weight to the testers were introduced or removed to maintain similar forage stubble height $(\approx 30 \mathrm{~cm})$ across experimental units. Herbage mass, nutritive value, stocking rate and average daily gain per head and per ha were evaluated.

\section{Results}

In south Florida, there was a quadratic decrease in herbage accumulation from 2.0 to $1.6 \mathrm{t} / \mathrm{ha}$ with decreasing stubble height. Conversely, herbage CP increased linearly with decreasing stubble height (from 14 to $17 \%$ ), while IVDOM was unaffected (66 vs 67\%). Mulato II ground cover decreased linearly from 87 to $74 \%$ as stubble height decreased from 12.5 to $2.5 \mathrm{~cm}$.

In central Florida, Hayday and Tifleaf 3 established more rapidly than Mulato II; however, Mulato II had greater herbage accumulation later in the fall. The perennial treatments (Mulato II and Tifton 85) had greater herbage accumulation overall than the annual treatments and Tifton 85 had greater ground cover than Mulato II in 2009 (73 vs 36\%) and 2010 ( 73 vs 12\%). Mulato II had greater IVDOM than Tifton 85 (67 vs 63\%), Hayday (64\%), and Tifleaf $3(62 \%)$.
In north Florida, in year 1, there were no differences in herbage allowance $(0.9 \mathrm{~kg} \mathrm{DM} / \mathrm{kg}$ body weight), average daily gain $(0.5 \mathrm{~kg} / \mathrm{d})$ and gain $/ \mathrm{ha}(168 \mathrm{~kg})$ among treatments. However, in year 2, Mulato II had greater herbage allowance (2.0 vs $0.7 \mathrm{~kg} \mathrm{DM} / \mathrm{kg} \mathrm{BW}$ ) and ADG $(0.78 \mathrm{vs} 0.41 \mathrm{~kg} / \mathrm{d})$ than Tifleaf 3 and Hayday but similar gain/ha (302 kg).

\section{Conclusions}

In central and north Florida, Mulato II may behave as an annual or biennial forage and its greater herbage accumulation and nutritive value make it a suitable alternative to Tifton 85 and warm-season annual forages. In contrast, in south Florida, Mulato II behaves as a perennial forage; however, forage persistence is reduced if it is cut to short stubble heights. This management strategy should be avoided.

\section{References}

Boddey RM; Macedo R; Tarré RM; Ferreira E; de Oliveira OC; Rezende CP; Cantarutti RB; Pereira JM; Alves BJR; Urquiaga S. 2004. Nutrient cycling of Brachiaria pastures: the key to understanding the process of pasture decline. Agriculture, Ecosystems and Environment 103:389-403.

Peters M; Franco LH; Schmidt A; Hincapié B.2003. Multipurpose forage species: Options for producers in Central America. CIAT Publication \# 333. International Center for Tropical Agriculture (CIAT), Cali, Colombia. 
Vendramini JMB; Sollenberger LE; Lamb GC; Silveira ML. 2013. Herbage accumulation, nutritive value and persistence of Mulato II in Florida. Tropical Grasslands - Forrajes Tropicales 1:123-124.

DOI: $\underline{10.17138 / \mathrm{TGFT}(1) 123-124}$

This paper was presented at the $22^{\text {nd }}$ International Grassland Congress, Sydney, Australia, 15-19 September 2013. Its publication in Tropical Grasslands - Forrajes Tropicales is the result of a co-publication agreement with the IGC 2013 Organizing Committee. Except for adjustments to the journal's style and format, the text is essentially the same as that published in: Michalk LD; Millar GD; Badgery WB; Broadfoot KM, eds. 2013. Revitalising Grasslands to Sustain our Communities. Proceedings of the $\mathbf{2 2}^{\text {nd }}$ International Grassland Congress, Sydney, Australia, 2013. New South Wales Department of Primary Industries, Orange, NSW, Australia. p. $213-214$. 